\title{
Constitutional limits to health-related nudging - a matter of balancing
}

VB verfassungsblog.de/constitutional-limits-health-related-nudging-matter-balancing-2/

Choice Architecture in Democracies Constitutional limits to health-related nudging - a matter of balancing Gertrude LübbeWolff Mo 5 Jan 2015

Mo 5 Jan 2015

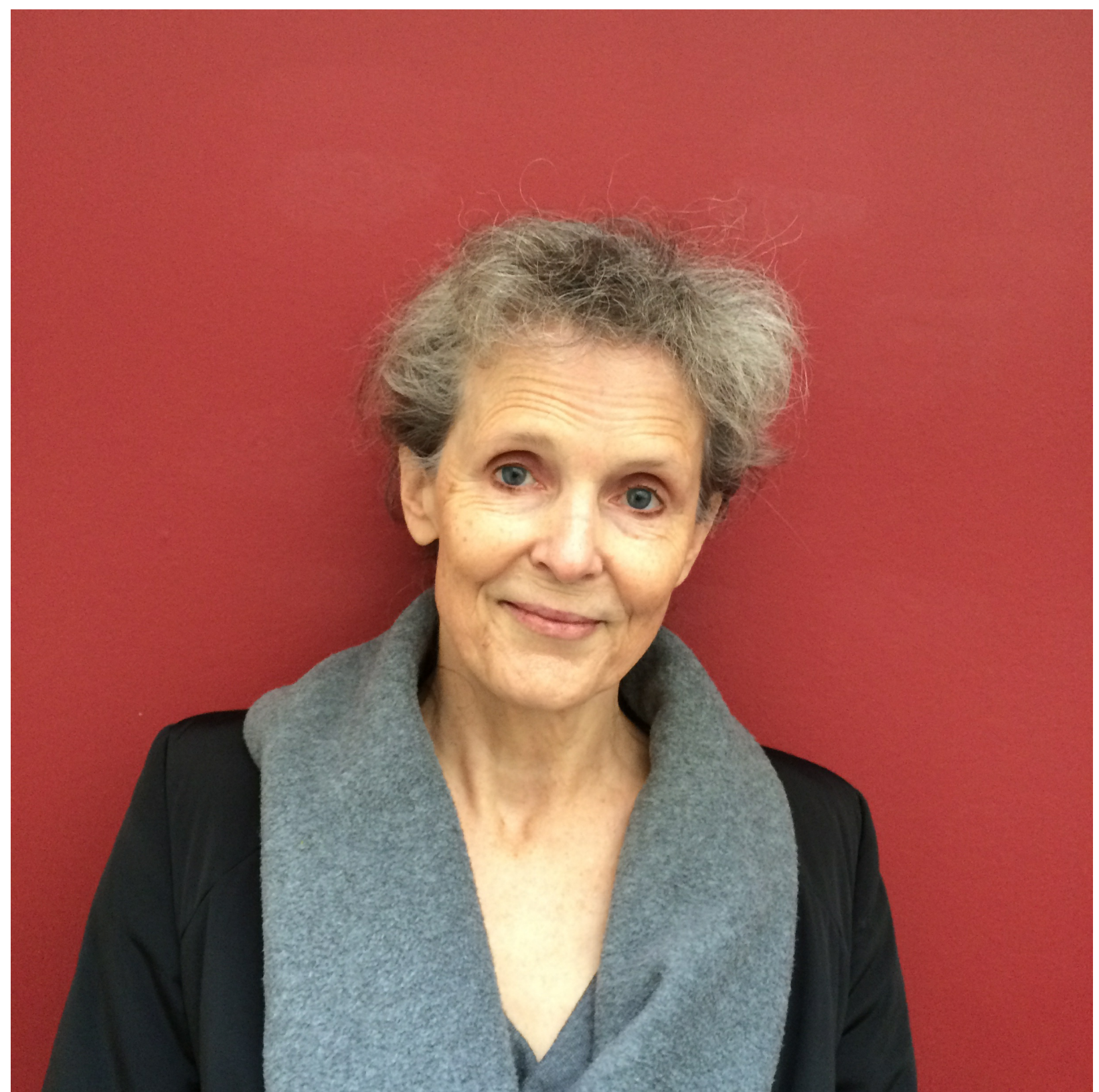

Politically as well as from the point of view of constitutional law, I see neither good reasons to generally reject health-related nudging towards less self-damaging behavior (1.), nor good reasons to issue a general clearance certificate on the grounds that nudging always leaves the addressee "at liberty" (2.). In both respects, I doubt that pondering or quarrelling over concepts of "embedded individualism" or "regulatory democracy" will bring us any closer to rationality of or consensus about the policy choices that have to be made. 
1. General rejection to any sort of auto-health-related nudging (with respect to accountable persons) would imply that whether, what, where and how much people smoke, drink and eat or whether they ever rise from their sofa or desk chair in order to get some exercise is a matter of no concern whatsoever to the state or any other public agency as long as only the respective individuals' own health, not that of others, is put at risk. That would amount to the view that the state must be neutral towards eating, drinking, smoking and physical inertia habits as it must be towards religious beliefs. To me, this view - which would leave people exposed to all sorts of nudging by private companies and circumstantial nudging without allowing the community to produce counterweights which only the community can provide effectively - has no plausibility whatsoever. And it is certainly not the view of the German Federal Constitutional Court (FCC).

The FCC has qualified public health as a community value of outstanding importance [1] capable of justifying interferences with fundamental rights guaranteed in the constitution. This qualification applies not only where state intervention aims at protecting health from being injured by others (as e.g. in the case of statutory reporting duties concerning contagious diseases[2]). To give just one example: Considering that in industrialized countries, more people die from smoking than from transport accidents, AIDS, alcohol, illegal drugs, murder and suicide taken together, and that in such countries smoking is the most frequent cause of death from cancer, the FCC held that warning people against these dangers is a legitimate state responsibility, and that legislation may also interfere with private companies' constitutionally protected freedom to exercise their trade by forcing them to print a warning on their tobacco products[3]. This applies not only to products sold to minors or other persons generally thought to be legitimate objects of paternalism, but to tobacco products in general. In other words: the state is not prohibited from taking sides in matters of public health - neither generally, nor specifically insofar as self-damaging behavior of accountable persons is concerned.

2. If that is so, the constitutional admissibility of health-related nudging will usually be a matter of balancing. It is insufficient to point to the fact that people who are just being nudged are free to resist the nudge. Nudges or regulations concerning nudges can interfere with constitutional rights in a variety of ways, for instance by shaming people, by forcing people or companies to nudge others - as in the case of mandatory warnings on tobacco products -, or by forcing people to opt.

Consider, for instance, nudging by default options, i.e. by selecting standard configurations which will apply unless individuals opt otherwise. Of the nudging examples given by Thaler and Sunstein, the most illustrative one is the idea of giving motor cyclists a choice with respect to wearing a helmet: The default option will be that they have to wear one, but they can get rid of that obligation by getting special biking training (or, in alternative designs: by showing that they have insurance, or by marking their bike as belonging to a registered organ donator). The installation of such a framework interferes with constitutional rights guaranteed under the German Basic Law (Grundgesetz, GG). This is easily overlooked because of a particular feature of the interference: its alternativity. The biker can choose between alternative restrictions of his constitutional liberty to act as he wishes[4], i.e. between the necessity to wear a helmet and the necessity to undergo extra training (or get insurance, or donate organs), but he will be subject to at least one of them. It is established 
FCC doctrine that interference with a constitutional right is not made constitutionally irrelevant by allowing to escape it via some alternative option which, if mandatory, would equally be an interference.[5]

Even where default options charging individuals with no more than a burden to "opt out" be it out of a pension scheme or out of donating their organs -, this may be a constitutionally relevant interference with their right to act (or omit) as they choose (Art. 2 I GG). Depending on form and frequency of the required act of opting, and probably also depending on the extent to which the default option can be presumed to be what most people want, such a burden may easily turn out excessive. Just imagine a statute according to which you bequeathe your fortune to the republic unless you have made a declaration to the contrary before a notary public no more than twelve months before your death. I am positive this would find no mercy before the FCC.

If frequency of the necessity to opt is one of the factors determining the weight of "burdens of opting out", the acceptability of mandatory default options may also depend on how many of them there are. In other words: If default options will turn out a favorite nudging instrument, as I guess they will, we might get a problem of incrementally summed-up opting-out-burdens. This type of burden is hard to control by a Constitutional Court whose immediate object of scrutiny is the incremental unit. Nevertheless - and, politically speaking: all the more - it ought to be taken into account from the outset in order to avoid heading towards a "smart republic" keeping us busy opting out of unwelcome choices.

[1] BVerfGE 7, 377 (406, 408, 414 f.); 11, 168 (186); 80, 1 (24).

[2] BVerfGE 32, 373 (380).

[3] BVerfGE 95, 173 (183 ff.).

[4] Art. 2 I GG. For the relevant broad reading of Art. 2 I GG see BVerfGE 80, 137 (153).

[5] See, e.g., 128, 109 (125); more explicitly BVerfG, decision of 28 november 2013 - 2 BvR 2784/12 - (www.bverfg.de).

\section{LICENSED UNDER CC BY NC ND}

SUGGESTED CITATION Lübbe-Wolff, Gertrude: Constitutional limits to health-related nudging - a matter of balancing, VerfBlog, 2015/1/05, https://verfassungsblog.de/constitutional-limits-health-related-nudging-matter-balancing$2 /$. 